\title{
Zaburzenia neurologiczne w przebiegu zakażenia ludzkim wirusem niedoboru odporności
}

\author{
Magdalena Sawczuk, Katarzyna Kapica-Topczewska, Jan Kochanowicz, Alina Kułakowska \\ Klinika Neurologii Uniwersytetu Medycznego w Białymstoku
}

\begin{abstract}
STRESZCZENIE
Zakażenie ludzkim wirusem niedoboru odporności (HIV, human immunodeficiency virus) stanowi problem globalny. Od początku lat 70 . XX wieku zakażonych było $100 \mathrm{mln}$ osób, a ponad $35 \mathrm{mln}$ zmarło z powodu zespołu nabytego niedoboru odporności (AIDS, acquired immunodeficiency syndrome). Zakażenie HIV początkowo ma charakter skąpoobjawowy, co utrudnia jego wykrycie. Wystąpienie powikłań neurologicznych może być zarówno objawem zakażenia HIV, jak i niepożądanym skutkiem leczenia. W przypadku pojedynczych ropni mózgu, neurotoksoplazmozy, encefalopatii o niejasnej etiologii, postępującej wieloogniskowej leukoencefalopatiii, kryptokokowego zapalenia opon mózgowo-rdzeniowych, postępującego otępienia, polineuropatii, chtoniaka pierwotnego mózgu, zespołu Guillaina-Barrégo czy poprzecznego zapalenia rdzenia kręgowego należy także wykonać badanie w kierunku zakażenia HIV.
\end{abstract}

Polski Przegląd Neurologiczny 2019; 15 (4), 218-224

Słowa kluczowe: Iudzki wirus nabytego niedoboru odporności (HIV), zespół nabytego niedoboru odporności (AIDS),

toksoplazmoza OUN, postępująca wieloogniskowa leukoencefalopatia (PML), zespót rekonstytucji immunologicznej (IRIS)

\section{WPROWADZENIE}

Zakażenie ludzkim wirusem niedoboru odporności (HIV, human immunodeficiency virus) stanowi problem globalny. Szacuje się, że od początku epidemii, która rozpoczęła się w latach 70. XX wieku, zakażonych było $100 \mathrm{mln}$ osób, a ponad $35 \mathrm{mln}$ zmarło z powodu zespołu nabytego niedoboru odporności (AIDS, acquired immunodeficiency syndrome). W 2018 roku na całym świecie żyło około $38 \mathrm{mln}$ osób zakażonych HIV, w tym 1,7 mln dzieci poniżej 15. roku życia, odnotowano $1,7 \mathrm{mln}$ nowych zachorowań. Około $75 \%$ osób zakażonych jest świadomych swojego statusu serologicznego, a spośród nich 79\% stosuje skojarzoną terapię antyretrowirusową. Do większości nowych zachorowań dochodzi w Afryce. Najwyższe ryzyko transmisji HIV dotyczy homoseksualnych mężczyzn, osób stosujących dożylnie narkotyki oraz osób świadczących usługi seksualne [1].
W Polsce od 1985 roku do końca 2018 roku zanotowano ponad 24 tys. zakażeń, ponad 3,7 tys. przypadków AIDS i 1,4 tys. zgonów z tego powodu [2]. Jednak te dane wydają się niedoszacowane. Liczba nowo rozpoznanych zakażeń HIV systematycznie wzrasta, co może się wiązać z częstszym wykonywaniem testów w tym kierunku. Na początku epidemii główną drogą zakażenia była dożylna podaż narkotyków, natomiast od 2001 roku obserwuje się przewagę infekcji przenoszonych drogą kontaktów seksualnych, zarówno homo- jak i heteroseksualnych.

Zidentyfikowanie HIV w 1983 roku pozwoliło opracować test do wykrywania przeciwciał anty-HIV. Obecnie znane są dwa typy wirusa: HIV-1, dominujący w Europie i Ameryce Północnej, oraz HIV-2, występujący głównie w Afryce Zachodniej. O infekcji HIV świadczy obecność materiału genetycznego wirusa, jednak testy molekularne na 
obecność HIV-RNA mają zastosowanie w bardzo ograniczonych sytuacjach klinicznych. Standardowo zaleca się wykonywanie przesiewowych testów serologicznych IV generacji służących wykrywaniu antygenu p24 oraz przeciwciał anty-HIV [3]. Testy te pozwalają na wykrycie bardzo wczesnego zakażenia HIV, bo już po około 2 tygodniach od ekspozycji. Jednak wynik ujemny, uzyskany przed upływem 12 tygodni od ryzykownego zdarzenia, wymaga powtórzenia - dopiero kolejny ujemny wynik po upływie tego czasu pozwala jednoznacznie wykluczyć infekcję HIV. W przypadku dodatniego wyniku również wymagane jest jego powtórzenie, z zastosowaniem innego testu z nowego pobrania krwi. Ponieważ uzyskanie dodatniego wyniku badania przesiewowego nie jest jednoznaczne z infekcją HIV, to ustalenie rozpoznania wymaga wykonania testu potwierdzenia, na przykład metodą Western blot, który pozwala również odróżnić zakażenie HIV-1 od HIV-2. Dodatni wynik potwierdza rozpoznanie infekcji HIV, natomiast wynik ujemny wymaga powtórzenia całej diagnostyki po upływie 2-4 tygodni. Po potwierdzeniu zakażenia HIV pacjenta należy skierować do poradni profilaktyczno-leczniczej.

Pierwszym lekiem zarejestrowanym przez Agencję ds. Żywności i Leków (FDA, Food and Drug Administration) w 1987 roku do leczenia infekcji HIV był preparat zydowudyny - Retrovir ${ }^{\circledR}$. Dopiero w 1996 roku pojawiły się doniesienia o skuteczności trójlekowego schematu leczenia, nazwanego wtedy wysoce aktywną terapią antyretrowirusową (HAART, highly active antiretroviral therapy). Obecnie w skojarzonej terapii antyretrowirusowej (cART, combined antiretroviral therapy) stosuje się nukleozydowe i nienukleozydowe inhibitory odwrotnej transkryptazy, inhibitory proteazy, inhibitory fuzji, inhibitory integrazy oraz inhibitory receptorów chemokinowych. Leczenie rozpoczyna się od dwóch nukleozydowych inhibitorów odwrotnej transkryptazy oraz nienukleozydowego inhibitora odwrotnej transkryptazy lub inhibitora proteazy. W wybranych szpitalach w Polsce funkcjonuje kompleksowa ambulatoryjna opieka specjalistyczna, zapewniająca wielokierunkowe działania zarówno profilaktyczne, jak i lecznicze osobom zakażonym HIV.

\section{PIERWOTNE ZAKAŻENIE RETROWIRUSOWE}

W 70-90\% przypadków zakażenie HIV początkowo przebiega pod postacią ostrej choroby retrowirusowej rozwijającej się po 4-6 tygodniach od ekspozycji. Ma postać nieswoistej infekcji wirusowej (określanej jako zespół mononukleozopodobny lub grypopodobny), w przebiegu której występują: gorączka, powiększenie węzłów chłonnych, zmęczenie, zapalenie gardła, utrata masy ciała, nocne poty, bóle mięśni i stawów, bóle głowy oraz nudności, wymioty czy biegunka. Obserwuje się również wysypkę plamisto-grudkową, zlokalizowaną głównie na tułowiu, a niekiedy także owrzodzenia w jamie ustnej i okolicy narządów płciowych. Objawy trwają około 14 dni, po czym następuje samoistna poprawa i przejście w fazę zakażenia utajonego.

Rzadko są obserwowane na tym etapie zakażenia powikłania neurologiczne, takie jak aseptyczne zapalenie opon mózgowo-rdzeniowych, odwracalna encefalopatia, leukoencephalitis, napady drgawkowe, poprzeczne zapalenie rdzenia, neuropatie nerwów czaszkowych lub obwodowych, zespół Guillaina-Barrégo, zapalenie wielomięśniowe, neuropatia splotu barkowego czy zapalenie zwojów nerwowych. Ich wystąpienie zawsze wymaga hospitalizacji i wiąże się z istotnie statystycznie niższą proporcją limfocytów CD4/CD8 oraz wyższą wiremią niż stwierdzana u pacjentów bez zajęcia układu nerwowego [4].

\section{INFEKCJE OPORTUNISTYCZNE}

Wystąpienie infekcji oportunistycznych zależy od stopnia immunosupersji.

\section{Toksoplazmoza ośrodkowego ukladu nerwowego}

Najczęstszą infekcją oportunistyczną jest toksoplazmoza - jednocześnie choroba wskaźnikowa AIDS. Do reaktywacji latentnego zakażenia pierwotniakiem Toxoplasma gondi dochodzi, gdy liczba limfocytów T CD4+ maleje poniżej 100/ $\mu$ l. Przeciwciała przeciwko T. gondi stwierdza się u 11$-67 \%$ populacji [5]. Odsetek osób seropozytywnych zwiększa się z wiekiem. Częściej seropozytywni są mężczyźni, osoby o niskim wykształceniu, żyjące na granicy ubóstwa [6]. U około 30\% 
pacjentów z AIDS, u których stwierdza się obecność przeciwciał przeciwko $T$. gondi, rozwinie się toksoplazmoza ośrodkowego układu nerwowego (OUN) [7].

Toksoplazmoza OUN charakteryzuje się przewlekłym przebiegiem, występowaniem bólów głowy, zaburzeń poznawczych, objawów ogniskowych, napadów drgawkowych oraz objawów wzmożonego ciśnienia śródczaszkowego. Podstawą diagnostyki są badania obrazowe, w których stwierdza się ogniska zapalne (najczęściej mnogie), wzmacniające się po podaniu środka kontrastowego, z obrzękiem okołoogniskowym, zlokalizowane głównie w zwojach podstawy, na granicy kory i podkorowej istoty białej oraz nadnamiotowo. W obrazowaniu metodą rezonansu magnetycznego (MRI, magnetic resonance imaging) mózgu w obrazach T2-zależnych stwierdza się charakterystyczne zmiany, ulegające obrączkowatemu wzmocnieniu pokontrastowemu ze wzmocniającym się okołościennym guzkiem (eccentric target sign). Dodatkowo za rozpoznaniem toksoplazmozy przemawia obecność przeciwciał w klasie IgG i dodatni wynik reakcji łańcuchowej polimerazy (PCR, polymerase chain reaction) na obecność antygenu pasożyta w płynie mózgowo-rdzeniowym (CSF, cerebrospinal fluid). W leczeniu toksoplazmozy stosuje się pirymetaminę oraz sulfadiazynę. Uzyskanie poprawy zarówno klinicznej, jak i radiologicznej pozwala ustalić rozpoznanie. W przypadku niepowodzenia terapii, tj. gdy dolegliwości utrzymują się dłużej niż 7 dni, a zmiany w MRI mózgu — dłużej niż przez 14 dni stosowania leczenia, wskazane jest pogłębienie diagnostyki o biopsję stereotaktyczną, tomografię emisyjną pojedynczego fotonu (SPECT, single-photon emission computed tomography) z zastosowaniem talu-201 lub pozytonowej tomografii emisyjnej (PET, positron emission tomography) w celu różnicowania z pierwotnym chłoniakiem mózgu.

\section{Kryptokokowe zapalenie}

\section{opon mózgowo-rdzeniowych i mózgu}

Najczęstszą przyczyną zapalenia opon mózgowo-rdzenowych w przebiegu infekcji HIV jest otoczkowy grzyb drożdżopodobny Cryptococcus neoformans, jednak notuje się także zwiększenie odsetka etiologii gruźliczej [8]. Kryptokokowe zapalenie opon mózgowo-rdzeniowych i mózgu zwykle poprzedza samoograniczające się, bezobjawowe zapalenie płuc. Przebieg jest podostry, występują objawy wzmożonego ciśnienia środczaszkowego. Nieleczona choroba prowadzi do śpiączki mózgowej i śmierci.

W badaniu tomografii komputerowej (CT, computed tomography) lub MRI mózgu obserwuje się cechy guza z efektem masy, poszerzone przestrzenie okołonaczyniowe i pseudocysty. Badanie CSF zaledwie w 40\% przypadków wykazuje niecharakterystyczne nieprawidłowości, takie jak niewielka pleocytoza jednojądrzasta. Obniżenie liczby leukocytów w CSF ( 20 leukocytów/ $\mu$ l) wiąże się z niekorzystnym rokowaniem [9]. Barwienie tuszem indyjskim preparatu bezpośredniego CSF pozwala wykryć charakterystyczną otoczkę grzyba. Zarówno w CSF, jak i we krwi można stwierdzić antygen kryptokokowy. W leczeniu infekcji kryptokokowej stosuje się amfotercynę B i flucytozynę, a w przypadku wysokiego ciśnienia śródczaszkowego wskazana może być punkcja odbarczająca lub drenaż komorowy.

\section{Postępująca wieloogniskowa leukoencefalopatia}

Postępującą wieloogniskową leukoencefalopatię (PML, progressive multifocal leucoencephalophaty) wywołuje wirus Johna Cunninghama (JCV, John Cunningham virus). Występuje ona u $3-5 \%$ pacjentów zakażonych HIV, gdy liczba limfocytów CD4 maleje poniżej 100/ $\mu \mathrm{l}$. W przebiegu PML obserwuje się zaburzenia poznawcze oraz stopniowo narastające objawy ogniskowe. Diagnostyka obejmuje wykonanie MRI mózgu, które uwidacznia niecharakterystyczne wieloogniskowe zmiany hiperintensywne w obrazach T2-zależnych i w sekwencji inwersji i powrotu (FLAIR, fluid-attenuated inversion recovery), hipointensywne w obrazach T1-zależnych, z predylekcją do lokalizacji w móżdżku, płacie potylicznym i pniu mózgu. W CSF zazwyczaj występują pleocytoza oraz zwiększone stężenie białka. Za rozpoznaniem przemawia dodatni wynik PCR na obecność DNA JCV. Nie ma leczenia celowanego, ale zastosowanie cART może przynieść poprawę, choć przebieg jest często letalny. 
Kryteria rozpoznania zespołu rekonstytucji immunologicznej (IRIS, immune reconstitution syndrome) (na podstawie [12])

I. Kryteria duże

A. Nietypowe objawy (przebieg) zakażeń oportunistycznych, guzów u osób, które odpowiedziały na cART:

- zlokalizowana choroba (np. węzły chłonne, wątroba, śledziona)

- znacznie nasilona reakcja zapalna (gorączka, bolesność zmiany)

- nietypowa reakcja zapalna (ziarniniaki, ropnie, martwica, okołonaczyniowe nacieki limfocytarne)

- pogorszenie funkcji narządu albo nasilenie zmian istniejących wcześniej, które uprzednio uległy regresji (po wykluczeniu toksyczności, lekooporności i innych nowych chorób)

B. Obniżenie stężenia HIV-RNA w surowicy > 1 log kopii/ml

II. Kryteria małe

Wzrost liczby limfocytów CD4 we krwi po zastosowaniu cART

Wzrost odpowiedzi immunologicznej na swoiste antygeny, np. odpowiedź DTH na antygeny prątków

Spontaniczne ustępowanie choroby, bez stosowania farmakoterapii i kontynuacji cART

CART (combined antiretroviral therapy) — skojarzona terapia antyretrowirusowa; HIV (human immunodeficiency virus) — ludzki wirus niedoboru odporności; DTH (delayed type hypersensitivity) — nadwrażliwość późna

\section{Cytomegawirusowe zapalenie mózgu}

Cytomegalowirus (CMV, cytomegalovirus) należy do rodziny Herpesviridae, charakteryzuje się długim okresem latencji po początkowo bezobjawowej infekcji pierwotnej [10]. W przypadku zaawansowanej immunosupresji, gdy liczba limfocytów CD4 wynosi poniżej 50 komórek/ $\mu \mathrm{l}$, dochodzi do reaktywacji zakażenia CMV. Może dochodzić do zajęcia mózgu, rdzenia kręgowego, zwojów i korzeni nerwowych oraz nerwów obwodowych. Badanie CSF może wykazać pleocytozę z komórkami wielojądrzastymi. W leczeniu stosuje się gancyklowir lub foskarnet. Wprowadzenie cART doprowadziło do zmniejszenia częstości występowania infekcji CMV [11].

\section{ZESPÓŁ REKONSTYTUCJI IMMUNOLOGICZNEJ}

Zespół rekonstytucji immunologicznej (IRIS, immune reconstitution syndrome) jest wyrazem nadmiernej odpowiedzi immunologicznej organizmu na zastosowanie cART i szybkiej odbudowy układu immunologicznego. Do jego wystąpienia predysponuje niska liczba CD4 - poniżej 100 komórek/ $\mu$ l oraz wysoka wiremia przy rozpoczynaniu leczenia, wcześniejszy brak terapii cART, szybki wzrost poziomu CD4 i obniżenie wiremii po zastosowanym leczeniu, a także współwystępowanie zakażeń oportunistycznych i niedokrwistości. Dochodzi do wystąpienia nowych objawów neurologicznych, nietypowych dla infekcji HIV, które pojawiają się najczęściej po 4-8 tygodniach od zastosowania efektywnego leczenia. W badaniu MRI mózgu obserwuje się niecharakterystyczne zmiany obrzękowe i wzmocnienie kontrastowe. Rozpoznanie IRIS (tab. 1 [12]) można ustalić, jeśli wystąpią wszystkie duże kryteria lub jeśli wystąpią duże kryteria A i dwa małe kryteria.

\section{PIERWOTNY CHŁONIAK MÓZGU}

Pierwotny chłoniak mózgu (PCNSL, primary central nervous system lymphoma) występuje w przebiegu zaawansowanego zakażenia HIV. Cechuje się obecnością objawów ogniskowych, tj.: niedowładu, objawów móżdżkowych, napadów drgawkowych i zaburzeń widzenia, zmian zachowania, zaburzeń funkcji poznawczych, oraz uszkodzeniem nerwów czaszkowych. Niekiedy występują zaburzenia wewnątrzwydzielnicze (moczówka prosta) i zespół hipowentylacyjny, związany z podwyższonym stężeniem kwasu mlekowego w CSF. Guz lokalizuje się w półkulach mózgu (może być jedno- lub wieloogniskowy) lub wewnątrzgałkowo. Badanie MRI mózgu wykazuje jedno lub większą liczbę ognisk, które wzmacniają się po podaniu środka kontrastowego i są otoczone strefą obrzęku. W obrazach SPECT i PET stwierdza się zwiększony wychwyt znacznika. W CSF można stwierdzić DNA wirusa Epsteina-Bárr (EBV, Epstein-Bárr virus) 
(EBV DNA). Biopsja stereotaktyczna pozwala na dokonanie rozpoznania. W leczeniu stosuje się radio- lub chemioterapię. Guz jest bardzo wrażliwy na podanie glikokortykosteroidów, po zastosowaniu których zmiany ogniskowe stwierdzane w MRI mózgu mogą przejściowo zaniknąć.

\section{ZMIANY NACZYNIOWE}

Pacjentów zakażonych HIV cechuje wyższe ryzyko udarów niedokrwiennego i krwotocznego mózgu. Rokowanie w tej grupie chorych jest podobne jak w populacji ogólnej [13]. Najczęstszą etiologią udaru pozostaje choroba małych i dużych naczyń, obserwuje się również wyższe ryzyko udaru kryptogennego [14]. Czynnikami ryzyka wystąpienia zmian naczyniowych są wysoki poziom wiremii i znaczne nasilenie immunosupresji, występowanie infekcji oportunistycznych (kryptokokowe zapalenie opon mózgowo-rdzeniowych, zakażenie $\mathrm{CMV}$, wirusem zapalenia wątroby typu C [HCV, hepatitis $V$ virus] czy Penicillium marneffei), nowotwory OUN (np. mięsak Kaposiego), zapalenie naczyń oraz zaburzenia gospodarki lipidowej związane z infekcją HIV. Wykazano, że stosowanie cART obniża ryzyko incydentów naczyniowych, jednak pozostaje bez wpływu na częstość ich występowania w grupie pacjentów z koinfekcją HCV. Profilaktyka zmian naczyniowych polega na skutecznym leczeniu infekcji HIV i eliminacji czynników ryzyka udaru typowych dla ogółu populacji.

\section{POWIKLANIA ZE STRONY}

\section{OBWODOWEGO UKLADU NERWOWEGO}

Zajęcie nerwów obwodowych często się obserwuje w przebiegu zakażenia HIV. Neuropatię czuciową HIV (HIV-SN, HIV-associated sensory neuropathy) w przeszłości uważano ze najczęstsze powikłanie zakażenia HIV. Obecnie, w zależności od populacji oraz regionu świata, może dotyczyć od kilku procent do 2/3 osób zakażonych HIV [15]. Dzięki stosowaniu skutecznej terapii, o mniejszym stopniu neurotoksyczności oraz wcześniejszemu jej rozpoczynaniu obserwuje się zmniejszenie liczby przypadków neuropatii czuciowej, a u osób nią dotkniętych przebieg choroby jest najczęściej asymptomatyczny lub podkliniczny [16].
W dystalnej symetrycznej polineuropatii występują bolesne parestezje w obszarze rękawiczek i skarpetek, początkowo zlokalizowane w kończynach dolnych, postępujące w ciągu tygodni i miesięcy. Z kolei neuropatię wywołaną toksycznym działaniem leków obserwuje się kilka miesięcy po zastosowaniu cART i jej objawy częściej są zlokalizowane w kończynach górnych. Najczęściej objawy neurotoksyczne obserwowano po zastosowaniu didanozyny, stawudyny i zalcytabiny. Neuropatia obwodowa w istotny sposób pogarsza jakość życia pacjentów, dlatego istotne jest leczenie objawowe bólu neuropatycznego i ewentualna modyfikacja leczenia antyretrowirusowego.

\section{SPEKTRUM ZABURZEŃ POZNAWCZYCH ZWIĄZANYCH Z HIV}

Zaburzenia poznawcze (HAND, HIV-associated neurocognitive disorder) są częstym problemem, mogą dotyczyć nawet do $70 \%$ pacjentów z infekcją HIV. Wyróżnia się:

- bezobjawowe zaburzenia poznawcze związane z HIV (ANI, asymptomatic neurocognitive impairment);

- łagodne zaburzenia poznawcze związane z HIV (MND, HIV-associated mild neurocognitive disorder);

- kompleks HIV-demencja (HAD, HIV-associated dementia) [17].

Do wystąpienia HAD predysponuje zaawansowanie infekcji (poziom CD4 < $200 \mathrm{kom} / \mu \mathrm{l})$, wiek powyżej 50. roku życia, płeć żeńska, choroby współistniejące (zwłaszcza infekcja HBV i HCV), stosowanie dożylnych narkotyków [18]. Najczęściej stwierdza się HAD u osób niestosujących terapii antyretrowirusowej, może być ona pierwszą manifestacją AIDS. Stosowanie CART obniża ryzyko wystąpienia HAD, ale go nie wyklucza. Nieleczony HAD prowadzi do śmierci po średnio 6-9 miesiącach. Charakteryzuje się współwystępowaniem otępienia podkorowego (zaburzone są pamięć świeża oraz funkcje wykonawcze) z narastającymi zaburzeniami ruchowymi (spowolnienie, parapareza, ataksja chodu) oraz zachowania, zwłaszcza w późniejszym okresie (objawy psychotyczne, halucynacje wzrokowe, słuchowe, zaburzenia snu, delirium). 
Diagnostyka obejmuje badania neuroobrazowe i CSF, ale kluczową rolę odgrywa badanie neuropsychologiczne. Użyteczne są skale przesiewowe, takie jak: Mini Mental State Examination (MMSE), HIV Dementia Scale (HDS), International HIV Dementia Scale (IHDS) [17]. Poza zaburzeniami poznawczymi wyraźnie ujawniają się także zaburzenia emocjonalne i behawioralne, takie jak podwyższony poziom lęku, obniżony nastrój, drażliwość, niepokój, apatia, zwiększona podatność na stres.

\section{MIELOPATIA WAKUOLARNA}

Mielopatia wakuolarna (HIVM, HIV-vacuolar myelopathy) występuje w zaawansowanej fazie zakażenia HIV. Charakteryzuje się powstawaniem wakuoli w obrębie słupów tylnych i bocznych istoty szarej w odcinku piersiowym rdzenia kręgowego. Objawy kliniczne to: stopniowo postępująca parapareza, prowadząca w konsekwencji do porażenia kończyn dolnych, zaburzenia chodu, zaburzenia czucia w obrębie kończyn dolnych, nietrzymanie moczu. Podstawami rozpoznania są obserwacja kliniczna oraz wykluczenie innych przyczyn mielopatii [19]. Istnieje jedynie objawowe leczenie; opisano przypadki poprawy po cART [20]. Prognozowana długość życia pacjentów z mielopatią wakuolarną w przebiegu zakażenia HIV to około 6 miesięcy. Częściej niż przyżyciowo jest ona rozpoznawana w badaniach pośmiertnych.

\section{OPIS PRZYPADKU}

Pracownik fizyczny w wieku 57 lat, żonaty (1 dorosły syn), mieszkaniec niewielkiej miejscowości został przyjęty do szpitala z powodu występujących od kilku tygodni trudności w chodzeniu, dolegliwości bólowych odcinka lędźwiowo-krzyżowego kręgosłupa i zmniejszenia masy ciała (w 6 miesięcy schudt o $10 \mathrm{~kg}$ ). Ponadto w wywiadzie ujawniono wrzodziejące zapalenie jelita grubego, cukrzycę typu 2, nadciśnienie tętnicze, nawracające zmiany ropne na skórze i przebyty przed kilkoma miesiącami półpasiec. Przy przyjęciu w badaniu neurologicznym stwierdzono objawy zespołu wiotkiego w zakresie kończyn dolnych i dodatnie objawy rozciągowe oraz białawy nalot na śluzówkach jamy ustnej. Badanie MRI odcinka lędźwiowego kręgosłupa wykazało zmiany dyskopatyczne na poziomie L4/L5 oraz L5/S1. Wyniki badań laboratoryjnych wskazywały na niedokrwistość normocytarną.

W badaniu CSF wykazano pleocytozę 450 kom/ $/ \mu \mathrm{l}$ z przewagą granulocytów obojętnochłonnych oraz podwyższone do $167 \mathrm{mg} / \mathrm{dl}$ stężenie białka. W celu dalszego leczenia chorego przeniesiono do kliniki chorób zakaźnych i neuroinfekcji, gdzie uzyskano dodatni wynik testu w kierunku HIV. Wiremia potwierdzona metodą PCR wynosiła 93800 kopii/ /ml. W badaniu cytometrycznym wykazano głęboki niedobór odporności; poziom limfocytów T CD3 + wynosił 394/ml (63\%), limfocytów T CD3+/ $/ C D 4+-42 / \mu \mathrm{l}$ (7\%), a limfocytów T CD3 + CD8+ - $338 \mu \mathrm{l} /(54 \%)$. U pacjenta rozpoznano AIDS.

Pogłębiony wywiad od chorego pozwolił na ustalenie drogi zakażenia, którą okazał się przypadkowy kontakt homoseksualny, który miał miejsce przed wielu laty (MSM, men who have sex with men). Pacjent nie zdawał sobie sprawy, że został zakażony wirusem HIV. Mimo intensywnego leczenia retrowirusowego i antybiotykoterapii o szeroki spektrum jego stan szybko się pogarszał. Wystąpiło zapalenie płuc, a następnie doszło do niewydolności oddechowej i zgonu.

\section{PODSUMOWANIE}

Zaburzenia neurologiczne mogą stanowić wczesną lub późną manifestację zakażenia HIV oraz być przejawem działań niepożądanych stosowanego leczenia antyretrowirusowego. Stwierdzenie niespecyficznych objawów neurologicznych oraz nietypowy przebieg dolegliwości powinny skłonić lekarza do poszerzenia diagnostyki o badanie serologiczne w kierunku zakażenia HIV. Wystąpienie objawów neurologicznych może być pierwszym objawem AIDS u osoby nieświadomej swojego statusu serologicznego. Obserwowane w przebiegu infekcji HIV dysfunkcje mogą dotyczyć zarówno OUN, jak i obwodowego układu nerwowego. W przypadku większości powikłań neurologicznych zakażenia HIV brakuje skutecznego leczenia celowanego, zazwyczaj pacjenci odnoszą największą korzyść z włączenia terapii antyretrowirusowej. 


\section{PIŚMIENNICTWO}

1. Global HIV \& AIDS Statistics - 2018 fact sheet. UNAIDS website. http://www.unaids.org/en/resources/fact-sheet (15.12.2019).

2. Dane wg Krajowego Centrum ds. AIDS na dzień 16.10.2019. https:// //aids.gov.pl (15.12.2019).

3. Szetela B, Łapiński Ł, Zalewska M. Zasady testowania w kierunku zakażenia HIV — zalecenia. In: Parczewski M, Bociąg-Jasik M, Inglot M, Mularska E, Witak-Jędra M. ed. Zasady opieki nad osobami zakażonymi HIV. Zalecenia PTN AIDS 2019. Polskie Towarzystwo Naukowe AIDS, Warszawa-Szczecin 2019: 10-19.

4. Ambrosioni J, Artigues F, Nicolás D, et al. Hospital Clinic PHI Investigators. Neurological involvement in patients with acute/recent HIV-1 infection. A case-control study. J Neurovirol. 2017; 23(5): 679-685, doi: 10.1007/s13365-017-0548-6, indexed in Pubmed: 28718069.

5. Santos AL, Terças Trettel AC, Ribeiro Ld, et al. Serological study on toxoplasmosis in the Haliti-Paresí community of the Utiariti indigenous territory, Campo Novo do Parecis, Mato Grosso, Brazil. Parasite Epidemiol Control. 2019; 5: e00097, doi: 10.1016/j.parepi.2019.e00097, indexed in Pubmed: 30886914.

6. Jones JL, Kruszon-Moran D, Elder S, et al. Infection in the United States, 2011-2014. Am J Trop Med Hyg. 2018; 98(2): 551-557, doi: 10.4269/ajtmh.17-0677, indexed in Pubmed: 29260660.

7. Montoya JG, Liesenfeld O. Toxoplasmosis. Lancet. 2004; 363(9425): 1965-1976, doi: 10.1016/S0140-6736(04)16412-X, indexed in Pubmed: 15194258.

8. Ellis J, Bangdiwala A, Cresswell F, et al. The changing epidemiology of HIV-associated adult meningitis, Uganda 2015-2017. Open Forum Infect Dis. 2019; 6(10), doi: 10.1093/ofid/ofz419, indexed in Pubmed: 31660375

9. Ferenczy MW, Marshall LJ, Nelson CDS, et al. Molecular biology, epidemiology, and pathogenesis of progressive multifocal leukoencephalopathy, the JC virus-induced demyelinating disease of the human brain. Clin Microbiol Rev. 2012; 25(3): 471-506, doi: 10.1128/CMR.05031-11, indexed in Pubmed: 22763635.

10. Zajkowska A, Kułakowska A. Wirusy Herpesviridae a stwardnienie rozsiane - powiązania etiopatogenetyczno-terapeutyczne. Pol Przegl Neurol. 2018; 14(1): 10-17.

11. Perello R, Vergara A, Monclus E, et al. Cytomegalovirus infection in HIV-infected patients in the era of combination antiretroviral therapy.
BMC Infect Dis. 2019; 19(1): 1030, doi: 10.1186/s12879-019-4643-6, indexed in Pubmed: 31801482.

12. Knysz B, Gąsiorowski J. Zespoły rekonstrukcji immunologicznej (ZRI) u osób zakażonych HIV. Zalecenia diagnostyczne i terapeutyczne. In: Parczewski M, Bociąg-Jasik M, Inglot M, Mularska E, Witak-Jędra M. ed. Zasady opieki nad osobami zakażonymi HIV. Zalecenia PTN AIDS 2019. Polskie Towarzystwo Naukowe AIDS, Warszawa-Szczecin 2019: 95-98.

13. Mapoure YN, Mondomobe CA, Nkouonlack C, et al. HIV infection does not influence stroke outcomes in HIV-infected patients: a prospective study. Rev Neurol (Paris). 2019; 175(5): 313-318, doi: 10.1016/j.neurol.2018.09.020, indexed in Pubmed: 30948261.

14. Chow FC, Price RW, Hsue PY, et al. Greater risk of stroke of undetermined etiology in a contemporary HIV-infected cohort compared with uninfected individuals. J Stroke Cerebrovasc Dis. 2017; 26(5): 1154-1160, doi: 10.1016/j.jstrokecerebrovasdis.2017.02.010, indexed in Pubmed: 28262563.

15. Adem KS, Janakiraman B, Gebremeskel BF, et al. Epidemiology and factors associated with peripheral neuropathy among HIV infected patients in Gondar, Ethiopia: A cross-sectional study. PLoS One. 2019; 14(1): e0211354, doi: 10.1371/journal.pone.0211354, indexed in Pubmed: 30695060.

16. Aziz-Donnelly A, Harrison TB. Update of HIV-associated sensory neuropathies. Curr Treat Options Neurol. 2017; 19(10): 36 , doi: 10.1007/s11940-017-0472-3, indexed in Pubmed: 28861848.

17. Kalinowska S, Trześniowska-Drukała B, Samochowiec J. Zaburzenia neuropoznawcze w przebiegu zakażenia wirusem HIV. Psychiat Pol. 2013; 47(3): 453-463.

18. Watkins CC, Treisman GJ. Cognitive impairment in patients with AIDS - prevalence and severity. HIV AIDS (Auckl). 2015; 7: 35-47, doi: 10.2147/HIV.S39665, indexed in Pubmed: 25678819.

19. Di Rocco A, Simpson DM. AIDS-associated vacuolar myelopathy. AIDS Patient Care STDS. 1998; 12(6): 457-461, doi: 10.1089/ /apc.1998.12.457, indexed in Pubmed: 11361993.

20. Bizaare M, Dawood H, Moodley A. Vacuolar myelopathy: a case report of functional, clinical, and radiological improvement after highly active antiretroviral therapy. Int J Infect Dis. 2008; 12(4): 442-444, doi: 10.1016/j.ijid.2007.09.014, indexed in Pubmed: 18082439 . 